\title{
Entrepreneurship in Adentan-Dodowa Localities- Challenges
}

\author{
Karikari Ama Foriwaa, Irene Akuamoah-Boateng \\ Department of Management Studies, School of Business, Valley View University, Oyibi, Ghana. \\ Email: kaanaff@yahoo.com
}

Received June 21 ${ }^{\text {st }}, 2012$; revised July 25 ${ }^{\text {th }}, 2012$; accepted August $27^{\text {th }}, 2012$

\begin{abstract}
Entrepreneurship is more than simply "starting a business". Entrepreneurship is a process through which individuals identify opportunities, allocate resources, and create value. This creation of value is often through the identification of unmet needs or through the identification of opportunities for change. In support of the assertion, Calvin (2003) said it is one of "today's most potentially rewarding avenues to gaining control over life and career". Therefore, entrepreneurs see "problems" as "opportunities", then take action to identify the solutions to those problems. Entrepreneurial success is a function of the entrepreneur's ability to see opportunities in the marketplace, initiate change (or take advantage of change) and creates value through solutions. They are an integral part of the renewal process that pervades and defines market economies. They are also the essential mechanism by which millions of people enter the economic and social mainstream of society. However, it is faced with a lot of challenges in Ghana, specifically Adentan-Dodowa localities. This research identified some challenges and realized that a common denominator for all entrepreneurs in that vicinity is the challenge of starting a business: be it through inventing something, looking for a new idea within a business, finding the right opportunity to break into a business or buying into a franchise. Questionnaires were used for data collection to discover the challenges of entrepreneurs.
\end{abstract}

Keywords: Entrepreneurship; SMEs

\section{Introduction}

The study of entrepreneurship has relevance today, not only because it helps entrepreneurs better fulfill their personal needs but because of the economic contribution of the new ventures (Calvin, 2003) [1]. More than increasing national income by creating new jobs, entrepreneurship acts as a positive force in economic growth by serving as the bridge between innovation and market place (Prof. Satish C. Ailawadi, ICFAI Business School) [2].

Contrary to the above assertion, modern school of thought on entrepreneurship claims that the role of an entrepreneur is innovativeness. Innovation is considered to be the strategic tool of entrepreneurs; this is one of the tools that enable them gain strategic advantage over competitors (QuickMBA, 2010) [3]. Creativity is the hallmark of entrepreneurship. Every entrepreneur is perceived to possess skills that enable him/her "to bring something out of nothing”. Hence, Schumpeter (1934) [4] "linked the entrepreneurial initiatives of individuals to the creation and destruction of industries as well as to economic development”. However, several other scholars have expressed their worldview about entrepreneurship on different levels of analysis-ranging from the individual to the economy-at-large (Davidsson \& Wiklund, 2001) [5] and (Putari, 2006) [6].

It can be inferred from statements above that the necessary characteristic of entrepreneurs is watchfulness. Several writers have expressed that entrepreneurs have the ability to perceive where market fails and to develop new goods or processes that the market demands but which are not currently being supplied (Penrose, 1963) [7]; (Leibenstein, 1968, 1979) [8]; (Gartner, 1988) [9]. Therefore, entrepreneurs have special ability to connect different markets and make up for market failures and deficiencies [4]. The key points to this discussion follow in three sections: the first frames the issues; the second delves into the challenges of SMEs; and the third probes potential strategies and tactics for fueling that pipelinesome currently underway, some easily implemented, and some worth considering for the future.

\section{Entrepreneurship Concept}

The word entrepreneur is derived from the French concept "entreprendre" which literarily is equivalent to the English concept "to undertake". From the business point 
of view, to undertake simply means to start a business [3]. An entrepreneur is one who organizes, manages, and assumes the risks of a business or enterprise. Often, individuals leave the job market, set up their own businesses or set up businesses due to one reason or the other. Considering the above statement, an "entrepreneur is regarded as a special kind of labour because not all labour possesses entrepreneurial abilities, which enable them to start a business from the scratch" (GST 307: Module for Entrepreneur Studies) [10]. Accordingly, entrepreneurship is simply the establishment of a new business or business enterprise or venture.

Hisrich and Peters reported that entrepreneurship is the "process of creating something new with value by devoting the necessary time and effort, assuming the accompanying financial, psychic, and social risks, and receiving the resulting rewards of monetary and personal satisfaction and independence" (2004: p. 10) [11]. The idea can also be looked at as "people or groups of people who exercises initiative by organizing a venture to take benefit of an opportunity and, as the decision maker, decides what, how, and how much of a good or service will be produced" (www.businessdictionary.com) [12]. An examination of both definitions indicates that there should be formation of something valuable to stakeholders-the entrepreneur as well as the market buyers. In return for the invested time and energy in producing the added value product, the entrepreneur is to receive benefits like independence and personal satisfaction [11].

The exploration of entrepreneurship reflected on the following categorization of entrepreneurs. Cox (Sept. 2002) [13] emphasizes on the types of entrepreneurs as:

- The Achiever-they are the people who are willing to extend the working hours in order to reach their respective personal goals set for operating the venture. The achievers plan to make things happen in their execution of duties at the business established. It should also be known that achievers possess the ability to create new and useful ideas that solve the challenges faced by the business.

- The Salesperson —entrepreneurs, as sales people, are often people-oriented. They seek the well-being of their clients. As a way of compensation, their customers buy from them "to show gratitude for the help offered by the salesperson”.

- The Manager - entrepreneurs, as managers, take charge of businesses by getting people along to build it. Managers lead by providing the necessary resources, and aiding in the rightful combination of the resources sought to produce products for consumption.

- The Inventor-such persons always think of creating something new and unique. According to Zimmerer and Scarborough (2008) creativity is the ability to develop new ideas and to discover new ways of look- ing at problems and opportunity” (p. 43) [14]. This trait can enable entrepreneurs, as inventor, to stand tall the business competition. Further, Cox report indicated that the inventors may be "idealistic and get carried away with their enthusiasm". That statement seems negative from my perspective because, being carried away might let people lose focus on whatever they are doing.

Similarly, ICSB World Conference [15] reveals other groupings of entrepreneurship as being ethnic and cultural entrepreneurship. The conference reported that "ethnic and cultural entrepreneurship has advanced the cause of equality while preserving cultures and traditions of aboriginal, immigrant, and artistic communities”. Such inclusion has expanded the potential impact of entrepreneurial principles as well as presenting new challenges.

Rockstar (2008) [16] identified the following as the types of entrepreneurs namely; Innovative, Imitating, Fabian and Drone.

- Innovative: This type of entrepreneur is thoughtful of introducing something new into the market. Their primary concern is in innovations, and thereby invests substantially in research and development to unearth new ways of doing things.

- Imitating: Such entrepreneurs are also termed to as the copy cats. They observe existing entrepreneurial skills and modify it to suit their business directions. They could "improve on an existing product, production process, technology and through their vision create something similar but better" [10]. This is the case of a student becoming better than the master.

- Fabian: They are the type of entrepreneurs who are very doubtful and cautious in every step made in the business life, especially in adopting changes. Apart from the named features of Fabian entrepreneurs, "they are lazy and shy to innovations, they are laggards" [10].

- Drone: These are those entrepreneurs who oppose to change. Another way of describing drone entrepreneurs is that they are conservative. That is, drones prefer to stick to their traditional or orthodox methods of production and systems.

In concluding on the types of entrepreneurs, all entrepreneurs have certain characteristics that make them unique as they journey through their business empire. Again, it can be said that they are motivated to become entrepreneurs due to their respective aspirations set.

\section{Methodology}

The researchers used questionnaires to gather data. Questionnaires were hand delivered by the researchers to Small and Medium Enterprises (SMEs) located between Adentan and Dodowa localities. According to the $\mathrm{Na}-$ 
tional Board for Small Scale Industries (NBSSI): "small enterprises are those that have 29 or less employees and enterprises whose capital investment requirements do not exceed the cedi equivalent of $\$ 100,000$ ” (Boachie-Mensah \& Marfo-Yiadom, 2005: p. 21) [17]. It should be noted that within the environment covered for the study, many of such businesses were not formally registered with the government. Hence, proper records were not kept by those businesses. Their practices have been to pay off daily taxes to the government representatives whenever they come around to inspect businesses transactions.

As a result of the nature of the work and the busy schedule of the respondents, it was convenient to leave the questionnaires and follow up. The researchers were ready with a tape to record interviews when granted but none of the respondents were willing to be interviewed. Out of the 30 questionnaire administered, 21 were retrieved. The core questions in the questionnaire centered on the challenges of small scale entrepreneurs and how these challenges can be addressed. Most importantly, these challenges need to be identified in order to adequately understand and draw up an entrepreneurial education which would equip the old and young entrepreneurs of today and the future with vital entrepreneur skills and knowledge.

\section{Discussion of Findings}

\subsection{Demographic Data}

According to ILO, the minimum age limit for defining the working age population needs to be specified by each country according to its national circumstances such as the compulsory schooling age, minimum age for admission to employment, and extent of child labour. These circumstances vary so greatly among countries that it is impossible to specify any universally applicable minimum age limit at the international level. Under Sections 89 and 90 of the Children's Act in Ghana, the minimum age of employment is fifteen years-sixty five years (World Bank, National Law and Polices on minimum ages). The survey (Figure 1) indicated that, the entrepreneurs falling within the labour age of 20 - 30 years was $40 \%, 25 \%$ of them were in age range $40-49$ years and $30 \%$ from ages 50 - 59 years. By inference, majority of the entrepreneurs are individuals who are mature and independent in thought and deeds. Remarkably, 30\% of the respondents were between the ages of 50 - 59 years. These individuals, maybe people who had gone through other jobs in life and had settled on their own business after so many experiences. Most of the respondents had secondary education (42.9\%) whiles $14.3 \%$ were without formal education (Figure 2).

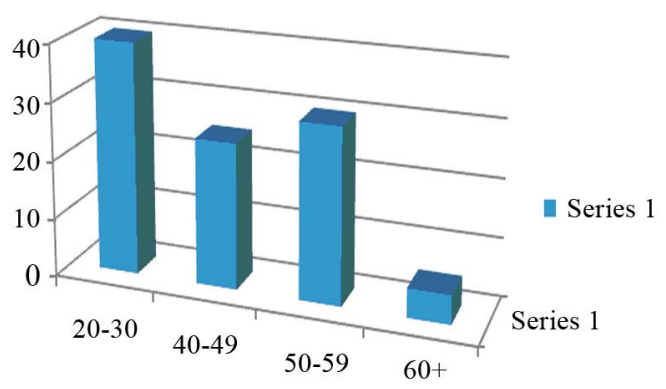

Figure 1. Age.

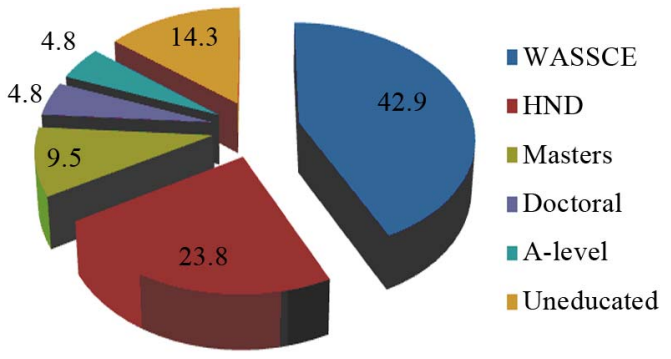

Figure 2. Educational background.

\subsection{Factors Influencing Business Setup}

Several factors influence the setting up of businesses in an economy but the study revealed the following:

Desire to be independent. $90.5 \%$ of the respondents reported that the business was influenced by their desire to be independent. Being their own boss and running the day-to-day activity of their business are the core goals of entrepreneurs.

Government policies. Unfavourable government policies have an impact on business establishment. Greater proportion of the populace (95.2\%) say that many entrepreneurs of today desire to set up businesses but due to the unfavourable government industrial policies (like high interest rate on loans, high tax system, unstable foreign currency, etc.) their dreams seem to be shattered. Continuously the Ghanaian cedi has depreciated, of which is causing the businessmen and businesswomen so dearly [1st half of 2012]. Such a situation is likely to disturb already existing businesses as well as yet to be established ones.

Difficulty of setting up your own business. From the analysis of the data, $76.2 \%$ of the respondents said it was not easy setting up their respective businesses. It may be due to difficulty in raising startup capital, lack of managerial skills, and bureaucracy of seeking permission from Accra Metropolitan Assembly to operate small-scale enterprises.

Other reasons indicated by respondents were: quest for more money, lack of white collar jobs, inspiration, the need to produce unique goods and services, and support family. 


\subsection{Respondents Perception of Entrepreneurs Contributions to Adentan-Dodowa Localities}

To assess entrepreneurs view on their contribution to the Adentan-Dodowa localities well-being, respondents were asked to list in order of importance their perception. With regards to perception, respondents rank developing new markets as their primary contribution to the national economy, followed by employment creation but the least contributory factors were discovering new sources of materials and mobilization of capital resources (Figure 3).

Entrepreneurship is "at the heart of national advantage” (Porter, 1990: p. 125) [18]. This presupposes that the work of entrepreneurs is of interest to everyone, since it comes with opportunities like job creation, availability of variety of products and self-actualization. It is, therefore, prudent that entrepreneurs establish the impact of their activities on the environs where they operate. This would go along way in affecting operational and administrative running of the business entities.

\subsection{Challenges of Entrepreneurship}

Sources of business idea. The idea generation of business is one of the crucial moments for establishing a business. Respondents narrated their experiences as to how to get a business started. Some of the sources indicated by them were through apprenticeship (9.5\%), from friends (19\%), and from family members (23.8\%). Starting the business was a challenge after getting the idea (76.5) due to so many factors but predominantly capital.

Pricing strategy of entrepreneurs. A little higher than $50 \%$ of the respondents agreed that the pricing of goods and services of small-scale business are on the high side. If that is the case, there is the likelihood for consumers to switch to other sellers whose produce are affordable. The purpose of consumers move is to enable them to save money for other activities.

Loan. It was revealed that assess to loan to facilitate, grow or expand business were challenges faced by entre-

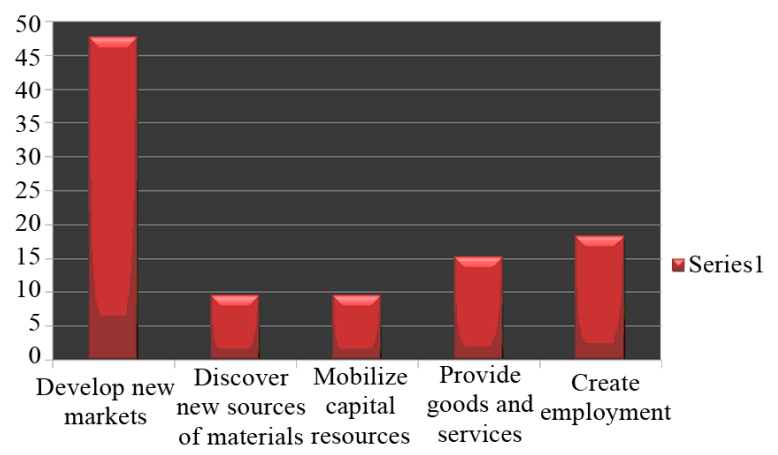

Figure 3. Respondents perception of entrepreneurs contributions toward Adentan-Dodowa localities. preneur (86\%). The banks according to majority of the respondents are willing to give out loans but the stress of paper work, interest rate, guarantor, and collateral, "go and come" syndrome simply wears you out. Individuals who are ready to provide loans either have very high rates or are bent on becoming share holders.

Choosing the right opportunity. The problem is that too many entrepreneurs never learn to say "no" to opportunities. It was established (79\%) that, in an effort to get their business off the ground and keep it up and running, they say "yes" to everything. They end up trying to do too much for too many, which dilutes their focus and often the quality of their product or service.

Delegation. For a business entity to grow, the entrepreneur must grow. When growth begins, the entrepreneur would find that he needs help from others to properly serve customers. The survey revealed that most (91\%) entrepreneurs do not like to give up control of any aspect of their business. Facing the fact that they cannot do it all on their own and that they must learn to rely on others to complete certain tasks (and not necessarily exactly how they themselves would do them) is a very hard reality.

Employee relations. Entrepreneurs often make employees part of a "family". The study indicated that, the challenge arises when someone in the "family" is not performing according to expectations and has to be terminated. Majority (61\%) entrepreneurs face an uphill battle in balancing loyalty and changing performance needs. If you let someone go who everyone else at the company loves or a poor performer stay you've created morale and emotional issues.

Other challenges identified and the corresponding percentages listed by respondents are stated below: high competition (53\%); lack of adequate formal education to record transactions (30\%); electricity and water problems (73\%); the influx of pirated brands (51\%) and managing cash flow (4.8\%).

\section{Conclusion}

Many people yearn to bring to fruition their dreams (business ideas) as well as creating a new venture, yet they are regularly constraint by challenges. The challenges are often not at all what one might expect. Business-oriented people perceived the risks factor as the biggest challenge of entrepreneurship. Yet the findings of the study reveal that the sources of business ideas, pricing of products, among others, are equally challenges of entrepreneurship. These challenges seem to cut across all forms of entrepreneurship.

\section{Recommendations}

Aid from the government. School of thoughts on entre- 
preneurs can be generalized as risk-bearers, coordinators and organizers, gap fillers, leaders, and innovators or creative imitators. Individuals are being encouraged to form new businesses in the form of tax incentives, buildings, roads, and a communication system to facilitate this creation process. Ideally, the encouragement by the Central Government is a factor to realize new enterprises. Governments should develop innovative industrial strategies for fostering entrepreneurial activity.

Would-be entrepreneurs should enroll in the formal education to acquire knowledge. The purpose of such suggestion is to enable persons with the intention of being entrepreneurs to be effective as well as efficient in their business operations. For instance, the education might introduce future entrepreneurs to records management, people management, and personal financial management. Additionally, Linda J. Cox asserted in her entrepreneurship article that education and training can encourage entrepreneurship. Specifically, she said entrepreneurs should be exposed to topics on achievement, business, individuals, groups, creativity and experience (Ctahr, Sept. 2002) [13].

The government ministry in-charge of business should encourage owners of small enterprises to properly register with the government. Such behaviors might be avenues for the government to earn revenue and in turn financially assist upcoming entrepreneurs.

\section{REFERENCES}

[1] R. J. Calvin, "Entrepreneurial Management: Creating Successful Business Plans Raising Capital and Structuring Deals Maximizing Profits and Growth,” McGraw-Hills, New York, 2003.

[2] S. C. Ailawadi, "Entrepreneurship Challenges in 21st Century,” 2012. www.iimmbangalore.org

[3] QuickMBA, “Entrepreneurship: Definition,” 2010. QuickMBA.com.http://QuickMBA.com

[4] J. A. Schumpeter, "The Theory of Economic Development,” Harvard University Press, Cambridge, 1934.

[5] D. Per and W. Johan, "Levels of Analysis in Entrepre- neurship Research: Current Research Practice and Suggestions for the Future,” Entrepreneurship Theory \& Practice, Vol. 25, No. 4, 2001, pp. 81-100.

[6] P. Vijith, “Re: Evolution of Entrepreneurship,” 2006. http://www.managementparadise.com/forums/entrepreneu rship/1118-evolution-entrepreneurship.html

[7] Penrose, “Re: Evolution of Entrepreneurship,” 1963. http://www.managementparadise.com/forums/entrepreneu rship/1118-Evolution-entrepreneurship.html

[8] H. Leibenstein, “Re: Evolution of Entrepreneurship,” 2006. http://www.managementparadise.com/forums/entrepreneu rship/1118-Evolution-entrepreneurship.html

[9] Gartner, “Re: Evolution of Entrepreneurship,” 1988. http://www.managementparadise.com/forums/entrepreneu rship/1118-Evolution-entrepreneurship.html

[10] Bhat and McCline, "GST 307: Module for Entrepreneur Studies,” 2005.

[11] R. D. Hisrich and M. P. Peters, "Entrepreneurship,” 5th Edition, McGraw-Hill, Boston, 2004.

[12] “Entrepreneurship,” 2010. http://www.businessdictionary.com/definition/entrepreneurship.html

[13] L. J. Cox, "Understanding Entrepreneurship,” College of Tropical Agriculture and Human Resources (CTAHR), Honolulu, 2002. http://www.ctahr.hawaii.edu

[14] T. W. Zimmer, N. M. Scarborough and Wilson, "Essentials of Entrepreneurship and Small Business Management," 5th Edition, Prentice-Hall, Upper Saddle River, 2008.

[15] Faculty of Management, "Types of Entrepreneurship and Entrepreneurs,” International Council for Small Business World Conference (ICSB, Canada). Hosted by Acadia Centre for Social and Business Entrepreneurship, Dalhousie University, Halifax, 2008.

[16] Rockstar, "GST 307: Module for Entrepreneur Studies," 2008.

[17] F. O. Boachie-Mensah and Marfo-Yiadom, "Entrepreneurship and Small Business Management," SuperTrade Complex, Accra, 2005.

[18] M. E. Porter, "The Competitive Advantage of Nations," Free Press, New York, 1990. 